\title{
UTCI APPLICATIONS IN PRACTICE (METHODOLOGICAL QUESTIONS)
}

\section{Krzysztof Błażejczyk ${ }^{1}$ (D) Magdalena Kuchcik ${ }^{2}$ (D)}

1, 2 Climate Impacts Laboratory, Institute of Geography and Spatial Organization

Polish Academy of Sciences

Twarda 51/55, 00-818 Warsaw: Poland

e-mails: kblaz@twarda.pan.pl' (corresponding author) • mkuchcik@twarda.pan.pl ${ }^{2}$

\begin{abstract}
UTCl, although it was developed with the participation of scientists from 22 countries, it has shortcomings and people using it face various obstacles. The difficulties include wide range of issues: from different availability of meteorological data in individual countries, through the kind of air temperature which should be properly used in calculations, or the need of recalculation of wind speed. However the biggest subject concern algorithms for mean radiant temperature (Mrt) calculations, different models and programs which simplify calculations of this complex index though introduce different approximations and, as a result, many false results. The paper presents also wide range of UTCl applications in urban bioclimate studies and bioclimatic mapping, climate-human health researches and biometeorological forecasts which were the primary purpose of the index creation, but also applications in tourism and recreation or even in bioclimate change analysis.
\end{abstract}

\section{Key words}

problems with UTCI in use $\cdot$ data bases - mean radiant temperature $\cdot$ mapping - human health

\section{Introduction}

In 2019, 10 years had passed since the creation of a new biometeorological indicator. Its creators named it the Universal Thermal Climate Index (UTCI). Work on the development of the index had been carried out since 1999 when a commission had been set up by the Biometeorological Congress in Sydney to create a new, universal indicator that could be used in a wide range of bioclimatic and biometeorological applications, irrespective of the climate zone. The indicator was also intended to fully reflect the real heat exchange processes inside the human body when the human body is in contact with ambient conditions. From 2006, parallel work had been carried out under Action 730 of the COST programme, with the participation of scientists from 18 European countries as well as from Israel, Canada, New Zealand and Australia.

After the work had been completed in 2009, the Index was presented to the scientific community at a number of conferences 
and in two dedicated publications. In 2012, a special issue of the International Journal of Biometeorology (vol. 56) was published. In 2013, a dedicated issue of Geographia Polonica (vol. 86, no. 1) presenting the outcomes of the earliest research based on the UTCI was released.

The present issue of GP follows the UTCI international conference entitled 'UTCl Assessment Measure in Human Bioclimatology - 10 Years of Application', which was held in Warsaw in May 2019. The conference was attended by about 70 people from 19 countries, and 40 papers and posters were delivered. In 2020, Miscellanea Geographica released a publication entitled 'UTCl application in different spatial and temporal scales' (https://content.sciendo.com/view/journals/mgrsd/mgrsdoverview.xml), which presents 5 conference papers. The Special Issue of the International Journal of Biometeorology, UTCI - 10 years of applications, is now in print. Its texts are available online on the Journal's website (https://link. springer.com/journal/484/online-first).

Over the 10 years, the UTCI was applied widely in research not only in the field of bioclimatology, but also in many related scientific disciplines. The most important of the UTCl applications include: assessment of regional and local features of bioclimate; urban bioclimate; recreation, tourism and sport; epidemiology and health research; biometeorological forecasts; climate change; occupational health; bioclimatic mapping. Some of the above issues will be addressed by the book 'Applications of the Universal Thermal Climate Index (UTCl) in Biometeorology', which is being prepared on the initiative of Eduardo Kruger from the Federal University of Technology of Paraná (Brazil).

The purpose of the present text is to discuss the key problems that the authors of UTCI-based research encountered while preparing and conducting it.

\section{Methodological questions}

When completing the work on the UTCl, its creators produced a methodological framework covering: the method for calculating the $\mathrm{UTCl}$, the preparation of sets of input data and the basis for interpreting UTCI values, including references to physiological processes occurring in the human body. However, in practice, the guidance offered by the UTCl recommendations has not always responded to the problems encountered by researchers. These problems can be divided into several groups: (1) the availability and quality of meteorological data necessary to calculate the UTCI, (2) the method of calculating the mean radiation temperature, (3) the determination of wind velocity, (4) the interpretation of the UTCI in non-standard applications (various forms of sport, recreation and tourism), (5) the creation of UTCl distribution maps.

\section{Availability of meteorological data}

The UTCl is used, inter alia, to assess the regional and local characteristics of a bioclimate. Such research relies on long or short sequences of meteorological observations from national networks of weather stations. Although measurements at meteorological stations are standardised, there are major differences both as regards the measurement and methods of observation (e.g. some meteorological services have switched to full automation of measurements at most stations) and the manner of their public presentation (e.g. digital and paper databases) and availability to researchers. Access to raw measurement data varies from country to country. In some of them (e.g. Poland, Germany, Ireland, Finland, Switzerland, Serbia, Russia, USA and Canada) point-in-time values of the various meteorological elements, including temperature, are generally available and there are no major problems with access to historical data (although the data series start dates vary between these countries). Nevertheless, in many countries access to point-in-time observational data is still limited or impossible to get. Therefore, some research is based on the results of researchers' own field measurements addressing a specific problem. 
In research practice, use is made of various global databases that are available. Examples include:

- synoptic messages (SYNOP and METAR), available for selected stations in the OGIMET database (https://www.ogimet. com/index.phtml.en),

- daily data published on NOAA websites (https://www.ncdc.noaa.gov/cdo-web/) and TuTiempo (https://en.tutiempo.net/ climate),

- the METEONORM database, containing hourly data for the Typical Meteorological Year (https://meteonorm.com/),

- database of the European Centre for Medium-Range Weather Forecasts (ECMWF) available at the Copernicus Climate Change Service C3S (https://cds.climate. copernicus.eu/).

Each of these databases has its own specificities, which researchers must bear in mind when undertaking research. For example, synoptic messages are coded. Naturally, they can be decoded by software, but it must be remembered that messages are archived in the form in which they have been generated at a given station and are made available by the national meteorological service. The database can have both coding errors and gaps for some observation dates. Besides, the database only includes post-2000 data.

The NOAA and TuTiempo databases contain daily values of some meteorological elements: mean, maximum and minimum temperatures, average air humidity (or dew point temperature), average and maximum wind velocity, gusts of wind, atmospheric pressure, rainfall totals, average horizontal visibility and/or general cloudiness. The use of average values in UTCl calculations can only be used for overall assessment of the bioclimate of a given place and cannot be used for analysing the thermal stress to which a person is subjected at a given moment and place, which will be discussed below.

The METEONORM database contains multi-annual monthly mean values for a wideranging set of meteorological data for various research periods. It includes, inter alia, hourly values of the meteorological elements necessary to calculate the UTCI (air temperature and humidity, wind velocity, total solar radiation, total cloudiness), which are generated on the basis of 10 -year observation sequences for the typical weather year. The typical meteorological year (TMY) is a set of meteorological data with data values for every hour in a year for a given geographical location. The data are selected from hourly data over a longer time period (normally 10 years or more). Therefore, these data are not suitable for studying long-term UTCl trends. Nevertheless, they can successfully be used for cross-regional (interregional) comparative research, both as regards the UTCl values themselves and the frequency of the different Index categories.

The ECMWF database contains global meteorological data from re-analyses and climate models. Meteorological variables were used to calculate worldwide historical gridded UTCI values and to draw UTCI maps (the automated routine implemented to generate ERA5-HEAT was developed as part of the Copernicus Climate Change Service C3S implemented by the ECMWF). The UTCI time series is a sequence of spatial grids at $0.25^{\circ}$ resolution (approximately $28 \mathrm{~km}$ at the equator) and 1-hour intervals (di Napoli et al., 2020a, b).

Despite the clearly easier access to meteorological databases than a dozen or so years ago, this problem persists. The authors of the indicator developed a statistical regression model in which the UTCl is a function of four meteorological variables: air temperature (ta), water vapour pressure (vp), wind velocity at a height of $10 \mathrm{~m}$ above the ground ( $\mathrm{v} 10 \mathrm{~m}$ ) and mean radiation temperature (Mrt). While the first three variables are standard data measured at meteorological stations, the Mrt should be determined on the basis of other source data. It should be added that the assessment scale of the UTCI refers to transient meteorological conditions. Therefore, a complete and reliable analysis of biothermal conditions can be made only 
on the basis of point-in-time data, from a specific observation date, e.g. 12 UTC, from several (3-8) observation dates, and even from 24 measurements per day. Below are some tips on how to perform UTCl calculations and how to interpret their results when the input data set is suboptimal.

\section{Air temperature}

Daily mean values of the meteorological elements used in some research are only useful in measuring the biometeorological conditions in a very general way, and are not suitable for assessing the actual thermal stresses on the body. For example, such data can be the basis for studying trends in thermal stress change over decades, but not for establishing the relationships between these trends and specific stress categories. Such an analysis can be used for comparing bioclimates of different places (provided that use is made of the same type of meteorological data for each of them), but cannot capture the thermal stress on a person at a given moment and place. Moreover, calculations based on daily mean values produce a 'flattened' picture of the annual cycle of the UTCl, with no information about extreme values.

To some extent, this problem may be solved by calculating the UTCI for maximum values of daily temperature, which are typically recorded in the early afternoon. This is exemplified by Warsaw data from 2019. The annual amplitude of the UTCI (calculated from monthly averages) is: $42.0^{\circ} \mathrm{C}$ for 12 UTC data (UTCI-12), $41.6^{\circ} \mathrm{C}$ for values based on the maximum daily air temperature (UTCl-max), and only $38.5^{\circ} \mathrm{C}$ for values based on the average daily temperature (UTCl-avg). In the months from October to March, there is a noticeable overestimation of UTCl-tmax in relation to UTCl-12, and from May to August, UTCl-12 was better reflected by UTCI-tmax than by UTCl-avg.

However, in order for daily values of meteorological variables ( $t$, tmax, tmin, $v, f$ and $N$ ) to be used for analysing thermal stress at specific times of the day, comparative studies must be carried out on the basis of reliable, independent observational material, linking the daily values of these elements with their values observed in a given geographic region at these specific times of the day. However, it should be remembered that they are approximate values that can produce probable UTCI values, and the categories of thermal stress assigned to them can only be treated as indicative.

\section{Wind velocity}

Another problem linked to input data is posed by the wind velocity thresholds at which the UTCl equation can be solved. It is recommended that these should be 0.5 and $30 \mathrm{~m} / \mathrm{s}$. Therefore, when undertaking these calculations, $0.5 \mathrm{~m} / \mathrm{s}$ should be adopted for velocities lower than the former of these thresholds. Regarding the upper threshold, $27 \mathrm{~m} / \mathrm{s}$ has been found to be a reasonable value. Failure to take into account the above velocity thresholds $(0.5$ and $27.0 \mathrm{~m} / \mathrm{s})$ in the calculations will lead to erroneous, highly unpredictable UTCl values.

It should also be remembered that the regression equation employed to calculate the UTCl uses wind velocity at a height of $10 \mathrm{~m}$ above the ground, which keeps the standard of meteorological stations. In the case of research based on a researcher's own field measurements, when the wind velocity is measured at a height of $1.5-2.0 \mathrm{~m}$ above the ground, it is necessary to convert the velocity to that at a height of $10 \mathrm{~m}$. There are several formulae for this purpose. The formula proposed by Liopo and Cycenko (1971) is relatively simple and often used:

$$
\mathrm{v}_{10 \mathrm{~m}}=\mathrm{v}_{\mathrm{w}}\left(10 / \mathrm{h}_{\mathrm{w}}\right)^{0.2}
$$

In the case of research on the UTCI within various city structures, Bröde et al. (2013) propose that the wind velocity be recalculated to $10 \mathrm{~m}$ using the above equation for wind velocity change with height. 
If wind velocity $(\mathrm{v})$ is expressed in knots or $\mathrm{km} /$ hour, it should be recalculated to $\mathrm{m} / \mathrm{s}$.

\section{Humidity}

In order to calculate the UTCI, it is necessary to use air vapour pressure (vp), expressed in hectopascals. When preparing a database, it is necessary to check in what units this meteorological variable is expressed and, if necessary, the pressure must be converted to hPa. The key software for calculating UTCl (e.g. BioKlima, RayMan) also allows relative humidity (f) and/or dew point temperature (td) to be entered instead of vp.

BioKlima uses the following conversion formulas for this purpose:

$$
\begin{aligned}
& v p=6.112 \cdot 10^{[7.5 \cdot t a /(237.7+t a)]} \cdot 0.01 \cdot f \\
& v p=6.11 \cdot e^{\{5417.753 \cdot[1 / 273.16]-[1 /(273.16+t d)]\}}
\end{aligned}
$$

\section{Mean radiant temperature}

Mrt is a value which characterises the thermal impact of solar and thermal radiation of the surroundings on man. Mrt represents a uniform surface temperature of an imaginary enclosure surrounding the person. According to the above definition, when calculating Mrt, account must be taken of both the fluxes of solar radiation (short-wave, Kglob and reflected Kref) that reaches humans, and of thermal radiation (long-wave), i.e. radiation emitted by the atmosphere (La), the ground surface $(\mathrm{Lg})$ and objects in our surroundings (trees, building walls, etc., Lo):

$$
M r t=f(\text { Kglob, Kref, La, Lg, Lo) }
$$

Naturally, the above general function $(f)$ requires the development of detailed algorithms, and unfortunately there is no onesize-fits-all solution in this regard. The original UTCl recommendations (Weihs et al., 2012) stressed that the calculation of Mrt should be based on data relating to individual short-wave and long-wave radiation fluxes taken from climate measurements or models.
In the initial period of UTCI research, the data were not widely available. Over the years, in the course of re-analyses by the ECMWF, the aforementioned global meteorological database was created on the basis of which point-in-time Mrt and UTCl values are calculated. These are freely available from the Climate Data Store, CDS, developed as part of the Copernicus Climate Change Service C3S implemented by the ECMWF (CDS 2020). Currently, the database covers the period after 1981, and its time step is 1 hour (di Napoli et al., 2020a, b), so it cannot be used in studies for pre-1981 timespans. In stationspecific research, it must be remembered that use must be made of data from the nearest $0.25^{\circ}$ grid node (approximately $28 \mathrm{~km}$ at the equator).

In the case of intra-urban bioclimates, numerous theoretical and experimental studies have been carried out to approximate the Mrt value as accurately as possible. The results of these studies are used in various computational fluid dynamics models, e.g. MITRAS (Schlünzen et al., 2003), ENVI-met (Brüse, 2004), SOLWEIG (Lindberg et al., 2008), MUKLIMO_3 (Sievers \& Früh, 2012; Sievers \& Kossmann, 2016), HURES (Park et al., 2014), UrbClim (de Ridder et al., 2015), and most recently PALM (Maronga et al., 2020). For built-up areas, use can also be made of the RayMan model (Matzarakis et al., 2010), which uses the VDI procedure to calculate Mrt (VDI, 2008; di Napoli et al., 2020b).

In studies based on standard meteorological data, the model most frequently used for calculating Mrt is the one implemented in the BioKlima 2.6 software. Based on the meteorological information available, the program selects one of the four models for determining Rprim, i.e. the amount of solar radiation absorbed by a nude man, namely: SolAlt (when only data on total cloudiness is available), SolGlob (when data on the intensity of total solar radiation is available), SolDir (when data on the intensity of direct and diffuse radiation is available) or SolVis (when only horizontal visibility data is available). 
Each of these models also requires information about the height of the sun on a specific observation date (Błażejczyk, 2004, 2005; Błażejczyk \& Kunert, 2011). Then, based on Rprim and other meteorological variables, Mrt is calculated using the following formula:

$$
\begin{aligned}
\operatorname{Mrt}= & {[(\text { Rprim }+0.5 \cdot \mathrm{Lg}+0.5 \cdot \mathrm{La}) /} \\
& \left.\left(5.384 \cdot 10^{-8}\right)\right]^{0.25}-273
\end{aligned}
$$

where:

$$
\begin{aligned}
\mathrm{La}= & 5.5 \cdot 10^{-8} \cdot(273+\mathrm{ta})^{4} \cdot \\
& {\left[0.82-0.25 \cdot 10^{(-0.094 \cdot 0.75 \cdot \mathrm{vp})}\right], } \\
\mathrm{Lg}= & 5.5 \cdot 10^{-8} \cdot(273+\mathrm{Tg})^{4}
\end{aligned}
$$

where:

La- backward sky radiation,

$\mathrm{Lg}$ - ground radiation,

ta - air temperature and

$\mathrm{Tg}$-ground surface temperature estimated as follows:

$\mathrm{Tg}=\mathrm{ta} \quad-($ for cloudiness, $\mathrm{N}>80 \%)$

$\mathrm{Tg}=1.25 \cdot \mathrm{ta}-\left(\right.$ for $\left.\mathrm{N}<80 \% \& \mathrm{ta}>0^{\circ} \mathrm{C}\right)$

$\mathrm{Tg}=0.9 \cdot \mathrm{ta}-\left(\right.$ for $\left.\mathrm{N}<80 \% \& \mathrm{ta}<0^{\circ} \mathrm{C}\right)$

When daily mean values of the meteorological variables are used to calculate the UTCl, use should be made of the height of the sun at noon, i.e. the one that represents the middle of the day.

\section{UTCI in selected applications}

Another methodological problem lies in determining the time of the day to which the UTCl will relate, the method for data analysis and interpretation, and the method for graphical/tabular presentation of data. The decision on these matters depends not only on the type and quality of the source meteorological data, but also on the purpose of the research. Studies by Błażejczyk et al. $(2010,2012)$ and Okoniewska (2020) demonstrate that the UTCl observed at noon shows the greatest intraday spatial differences, even over a small area. Therefore, most bioclimatic studies typically rely on the UTCI value observed at noon when the greatest outdoor human activity and the greatest variation in thermal stress conditions, and thus the greatest human exposure to this stress, are observed. The remaining problems identified above will be discussed based on the example of the use of the UTCl in research on urban bioclimate, tourist and recreational evaluations, climate impacts on mortality and morbidity, UTCI mapping, and assessments/ forecasts of bioclimate changes, including thermal stress conditions.

\section{Urban bioclimate}

In the modern world, most of the population is concentrated in cities. Therefore, studies of the climate and bioclimate of cities are widely undertaken on all continents and at all latitudes. Urban thermal stresses are usually compared to those observed at extra-urban stations. As with regional studies, use is made of the same UTCl measures (Makosza \& Nidzgórska-Lencewicz, 2011; Bröde et al., 2013; Nowosad et al., 2013; Błażejczyk et al., 2014a, b; Lukić \& Milovanović, 2020). In urban bioclimate research, the UTCI may be, and is likely to be, increasingly based on modelled data on account of their availability.

Relying on field measurements is another approach to research on bioclimatic differences. Measurement campaigns are relatively short (from a few days to several weeks) and are conducted in various city locations with different types of management and development. Such research conducted in Warsaw housing estates in 2013 demonstrated a strong relationship of the UTCI not only with the size of the biologically active area, but also with the spatial structure of the estate (Błażejczyk et al., 2014a, b). Short series of measurements aimed at assessing the possibility of using the UTCI for landscape planning and design were conducted in Canada and South Korea (Park et al., 2014) and Brazil (Bröde et al., 2012). The effect of urban greenery, especially parks, on thermal stress in cities has been researched by field 
studies in Florence (Petralli et al., 2020) and in Warsaw (Błażejczyk et al., 2014b; Kuchcik et al., 2016). The greatest challenge in such surveys lies in locating the measuring station so as to ensure that its siting is representative of the spatial unit under study and, at the same time, safe, as well as in engaging a sizable group in the research.

In assessing the bioclimate of a city and its surroundings, especially if the city has a varied topography, use can be made of UTCI values calculated using a simplified formula (Błażejczyk et al., 2014a), in which Mrt takes into account factors affecting change in solar radiation which depend on the landform, land cover and land development, factors that are very variable in cities (Błażejczyk, 2011a). Such approximations are useful in modelling biothermal urban conditions in different types of weather, with various values of the set of meteorological elements. Such studies have been conducted, inter alia, in Warsaw (Błażejczyk, 2011b), Lublin (Dobek et al., 2013), or in the cities of the Ziemia Kłodzka region in Poland (Milewski, 2013).

\section{Human health}

As the key purpose of the UTCI is to determine how the human body responds to the surrounding thermal environment, using the UTCl in research on the effect of thermal conditions on the relationship between morbidity and mortality is a very natural theme of interest. Heat stress mortality studies differ in terms of the approach to UTCI. Sometimes, predetermined UTCl thresholds defined by the creators of the Index are used. These define the individual types of thermal stress, and the increase/decrease in mortality due to the different types is analysed. This was done by researchers in Moscow, who studied deaths caused by individual groups of diseases (Shartova et al., 2019), in the city of Mashhad, Iran (Fallah Ghalhari \& Mayvaneh, 2016), or in various regions of Poland (Błażejczyk $A$. et al., 2018). This approach does not take into account the adaptation of a given population to the climate where they live (Błażejczyk
\& McGregor, 2007). Nevertheless, it is useful in comparing different places with each other and with the results of research teams from different countries.

The 10\% and $90 \%$ quantiles of the UTCl, and even $5 \%$ in winter and $95 \%$ in summer (Urban \& Kyselý, 2014) can also be adopted as the thresholds above/below which mortality or morbidity is analysed. Such an approach takes into account the climatic conditions of the place and people's adaptation to the climate, and, in fact, marks the extreme conditions.

The third way is not to adopt any strict assumptions about the UTCI. In such a case, the curves of the dependence of mortality on the UTCl are determined using regression methods, typically the Generalised Additive Model, with increases/decreases in mortality shown above/below specific UTCI values. This was more or less how - albeit with the use of data from reanalysis and grid data - mortality in many European cities in the years 1979 . 2016 was examined (di Napoli et al., 2018), and how, based on actual data, mortality for groups of diseases in several Polish cities in the years 1975-2014 were studied (Kuchcik, 2017, 2020). The second method allows, inter alia, an increase/decrease in mortality to be attributed to each $1^{\circ} \mathrm{C}$ of increase/decrease in the UTCl and best describes the actual relationship between the phenomena studied. This method was also used to study flu episodes and their dependence on the UTCI (Lindner-Cendrowska \& Bröde, 2021) and in a study of cardiovascular morbidity in the Iberian Peninsula (Santurtún et al., 2020).

The UTCl is also used for assessing the therapeutic potential of Poland (Kuchcik et al., 2013) and how the bioclimatic conditions of health resorts relate to the needs of spa operators, a topic which has been worked on for over a dozen years at the Climate Impacts Laboratory at the Institute of Geography and Spatial Management of the Polish Academy of Sciences. Here, the main purpose is to determine the frequency of days and spells when cold or hot stress may constrain the use of climatotherapy and even threaten the health of patients. 


\section{Tourism and recreation}

Tourism and recreation are among the key aspects of human lives. Bioclimatic studies take into account various forms of physical activity and different weather scenarios. The aim of such research is to identify the places where and times when the exercise of various physical activities is the most beneficial. The book by Błażejczyk and Kunert (2011) is a comprehensive compendium of methods (including the UTCl) which can be used in such studies.

In the case of day- or hours-long forms of recreation and tourism, it is important to identify the biothermal contrasts, if any, between different times of day and between successive days (Błażejczyk, 2011a; Kuchcik et al., 2013; Pecelji et al., 2021).

Biothermal contrasts can also be the basis for large-area research, when tourism changes the climatic conditions quickly and drastically. The practical purpose of such research is to propose recommendations on how to prepare for a trip to a different climate zone (Błażejczyk \& Vinogradova, 2014).

Traditional methods and indicators for assessing climate from the perspective of tourism and leisure pertain to so-called human thermal sensations. This way of assessing the thermal environment is sometimes transferred to the interpretation of the UTCI. This is a fundamental mistake, as the UTCl assessment scale refers to thermal stress. The same type of thermal stress may be felt by individuals or populations as a stimulus causing different thermal sensations. In recent years, research has been initiated on the perception of the thermal environment, both from the perspective of thermal sensations and thermal stress. UTCl field measurements and surveys of various groups of respondents have been carried out in Curitiba, Brazil (Krüger, 2017) and in Warsaw (Lindner-Cendrowska \& Błażejczyk, 2018). During the 2019 UTCI conference in Warsaw, an initiative was proposed to create a global database with data on thermal perception in various climate zones and types of environment. The project is coordinated by Kevin Ka-Lun Lau from the Institute of Future Cities, the Chinese University of Hong Kong and Eduardo Krüger from Universidade Tecnologica Federal do Parana, Curitiba, Brazil. In order to join the project, readers should contact one of the coordinators.

\section{Bioclimatic mapping}

One of the important aims of climatic and bioclimatic studies is to define the spatial differentiation of particular climate elements and/or bioclimatic indicators. Several methods of UTCI mapping are in use. In general, authors apply isoline maps, based on point data (usually meteorological stations) (Vinogradova, 2020; Kuchcik et al., 2021), raster maps (Milewski, 2013; di Napoli et al., 2020a) or typological maps (Błażejczyk \& Błażejczyk, 2014). Recent years have brought a new source of meteorological data taken from climatic re-analysis undertaken in the European Centre for Medium-Range Weather Forecasts (ECMWF). Meteorological variables were used by di Napoli et al. (2020b) to calculate worldwide historical gridded Mrt and UTCI data and to draw UTCI maps. The automated routine implemented to generate ERA5-HEAT provides UTCl time series as a sequence of spatial grids of $0.25^{\circ}$ resolution and 1 -hour intervals. ECMWF and ERA5-HEAT data are applied in raster mode for regional research.

The typological maps are based on Błażejczyk's method developed in 2002 (Błażejczyk, 2002) and modified by Kunert (2010). The method can be applied in UTCI mapping on a local scale, assuming different types of weather. Maps such as those already mentioned in the context of city bioclimate research have been prepared, inter alia, for Warsaw (Błażejczyk, 2011b), Lublin (Dobek et al., 2013), cities of the Ziemia Kłodzka region (Milewski, 2013), and for some Polish health resorts (Błażejczyk et al., 2014a).

Recently, researchers from China have attempted to use satellite imagery and surface temperature in UTCl mapping. 
However, although reference was made to meteorological station measurements, the entire procedure seems disputable. The successive levels of data modelled under various assumptions on the basis of which the UTCI was calculated in a simplified way make it difficult to say what the maps actually show (Wang et al., 2020).

\section{Bioclimate change analysis}

In recent years, great importance has not only been attached to climate change, but also to bioclimate changes. The UTCI has been used to analyse multi-annual trends of changes in hazardous heat and cold stress in humans in many cities in Poland in the period 1951-2018 (Kuchcik et al., 2021) or in the cities of Lower Silesia in the years 1966-2017 (Głogowski et al., 2020).

The UTCl is also used in forecasting bioclimate changes according to various scenarios. For example, in the analysis of the German bioclimate forecast for the years 2031-2050, the input data consisted of UTCI values obtained using the COSMOCLM model, which were superimposed on a digital terrain model. This produced maps of Germany with the potential number of days with different intensities of thermal stress and different lengths of spells with oppressive weather (Brecht et al., 2020). Another example of how the UTCI can be used in forecasting is the analysis of human exposure to thermal stress in Vienna's street canyons in the light of the changing climate and increasingly frequent heatwaves, which was also carried out using modelled climatic data with different temporal and spatial resolution based on the Corine land surface dataset (Trimmel et al., 2021). When conducting such analyses, it must be borne in mind that they are based on modelled data and present a very approximate picture of the future.

Climate change forecasts based on various SRES scenarios (A2, A1B, B1) have also been the basis for predicting changes in thermal stress according to the UTCl. They have, for instance, been completed for Poland (Błażejczyk et al., 2013, 2018, 2020) and Hong Kong (Cheung \& Hart, 2014).

Editors' note:

Unless otherwise stated, the sources of tables and figures are the authors', on the basis of their own research.

\section{References}

Błażejczyk, A., Błażejczyk, K., Baranowski, J., Kuchcik, M. (2018). Heat stress mortality and desired adaptation responses of healthcare system in Poland. International Journal of Biometeorology, 62(3), 307-318. https://doi.org/10.1007/s00484-017-1423-0

Błażejczyk, K. (2002). Znaczenie czynników cyrkulacyjnych i lokalnych w kształtowaniu klimatu i bioklimatu aglomeracji warszawskiej. Dokumentacja Geograficzna, 26, Warsaw: IGiPZ PAN.

Błażejczyk, K. (2004). Radiation balance in man in various meteorological and geographical conditions. Geographia Polonica, 77(1), 63-76.

Błażejczyk, K. (2005). Radiation balance of different segments of the human body. 17th International Congress of Biometeorology ICB 2005, Annalen der Meteorologie, 41(1), 313-316. Offenbach am Main: Deutscher Wetterdienst.

Błażejczyk, K. (2011a). Assessment of regional bioclimatic contrasts in Poland. Miscellanea Geographica, 15, 77-91. https://doi.org/10.2478/v10288-012-0004-7

Błażejczyk, K. (2011b). Mapping of UTCl in local scale (the case of Warsaw). Prace i Studia Geograficzne WGSR UW, 47, 275-283. 
Błażejczyk, K., Baranowski, J., Błażejczyk, A. (2018). Climate related diseases. Current regional variability and projections to the year 2100. Quaestiones Geographicae, 37, 1, 23-36. https://doi.org/10.2478/quageo-2018-0003

Błażejczyk, K., Błażejczyk, A. (2014). Assessment of bioclimatic variability on regional and local scales in Central Europe using UTCl. Scientific Annals of "Alexandru loan Cuza" University of lași, 60(1), 67-82.

Błażejczyk, K., Błażejczyk, A., Baranowski, J., Kuchcik, M. (2020). Assessment of mortality risk in Poland due to cold and heat stress and predictions to 2100. Journal of the Climate Change Research, 1(4), 67-75. https://doi.org/10.30488/CCR.2020.252534.1028

Błażejczyk, K., Bröde, P., Fiala, D., Havenith, G., Holmér, I., Jendritzky, G., Kampmann, B. (2010). UTCl Nowe narzędzie badania warunków bioklimatycznych w różnych skalach czasowych i przestrzennych. Przeglad Geofizyczny, 55(1-2), 5-19.

Błażejczyk, K., Epstein, Y., Jendritzky, G., Staiger, H., Tinz, B. (2012). Comparison of UTCl to selected thermal indices. International Journal of Biometeorology, 56(3), 515-535. https://doi.org/10.1007/s00484-011-0453-2

Błażejczyk, K., Idzikowska, D., Błażejczyk, A. (2013). Forecast changes for heat and cold stress in Warsaw in the 21st century, and their possible influence on mortality risk. Papers on Global Change, 20, 47-62.

Błażejczyk, K., Kuchcik, M., Błażejczyk, A., Milewski, P., Szmyd, J. (2014a). Assessment of urban thermal stress by UTCl - experimental and modelling studies: an example from Poland. Erde, 145(1-2), 16-33. https://dx.doi.org/10.12854/erde-145-3

Błażejczyk, K., Kuchcik, M., Milewski, P., Dudek, W., Kręcisz, B., Błażejczyk, A., Szmyd, J., Degórska, B., Pałczyński, C. (2014b). Miejska wyspa ciepła w Warszawie. Uwarunkowania klimatyczne i urbanistyczne. Warsaw: Wydawnictwo Akademickie SEDNO.

Błażejczyk, K., Kunert, A. (2011). Bioklimatyczne uwarunkowania rekreacji i turystyki w Polsce. Monografie, 13. Warsaw: IGiPZ PAN.

Błażejczyk, K., McGregor, G. (2007). Warunki biotermiczne a umieralność w wybranych aglomeracjach europejskich. Przeglaqd Geograficzny, 79(3-4), 401-423.

Błażejczyk, K., Vinogradova, V. (2014). Adaptation Strain Index for tourists traveling from central and northern Europe to the Mediterranean. Finisterra, 49(98), 139-157. https://doi.org/10.18055/Finis6465

Brecht, B.M., Schädler, G., Schipper, J.W. (2020). UTCl climatology and its future change in Germany an RCM ensemble approach. Meteorologische Zeitschrift, 29(2), 97-116.

https://doi.org/10.1127/metz/2020/1010

Bröde, P., Błażejczyk, K., Fiala, D., Havenith, G., Holmér, I., Jendritzky, G., Kuklane, K., Kampmann, B. (2013). The Universal Thermal Climate Index UTCl compared to ergonomics standards for assessing the thermal environment. Industrial Health, 51(1), 16-24. https://doi.org/10.2486/indhealth.2012-0098

Bröde, P., Krüger, E.L., Rossi, F.A., Fiala, D. (2012). Predicting urban outdoor thermal comfort by the Universal Thermal Climate Index UTCl - a case study in Southern Brazil. International Journal of Biometeorology, 56(3), 471-480. https://doi.org/10.1007/s00484-011-0452-3

Brüse, M. (2004). ENVI-met 3.0: Updated Model Overview. University of Bochum. http://www.envi-met.net/documents/papers/overview30.pdf

CDS. (2020). Thermal comfort indices derived from ERA5 reanalysis. https://doi.org/10.24381/cds.553b7518

Cheung, C.S.C., Hart, M.A. (2014). Climate change and thermal comfort in Hong Kong. International Journal of Biometeorology, 58(2), 137-148. https://doi.org/10.1007/s00484-012-0608-9

de Ridder, K., Lauwaet, D., Maiheu, B. (2015). UrbClim - a fast urban boundary layer climate model. Urban Climate, 12, 21-48. https://doi.org/10.1016/j.uclim.2015.01.001

di Napoli, C., Barnard, Ch., Prudhomme, Ch., Cloke, H.L., Pappenberger, F. (2020a). ERA5-HEAT: A global gridded historical dataset of human thermal comfort indices from climate reanalysis. Geoscience Data Journal. https://doi.org/10.1002/gdj3.102 
di Napoli, C., Hogan, R.J., Pappenberger, F. (2020b). Mean radiant temperature from global-scale numerical weather prediction models. International Journal of Biometeorology, 64(7), 1233-1245. https://doi.org/10.1007/s00484-020-01900-5

di Napoli, C., Pappenberger, F. Cloke, H.L. (2018). Assessing heat-related health risk in Europe via the Universal Thermal Climate Index (UTCI). International Journal of Biometeorology, 62(7), 1155-1165. https://doi.org/10.1007/s00484-018-1518-2

Dobek, M., Demczuk, P., Nowosad, M. (2013). Spatial variation of the Universal Thermal Climate Index in Lublin in specified weather scenarios. Annales Universitatis Mariae Curie-Skłodowska Lublin-Polonia, Sectio B, 68(1), 21-37.

Fallah-Ghalhari, G., Mayvaneh, F. (2016). Effect of air temperature and universal thermal climate index on respiratory diseases mortality in Mashhad, Iran. Archives of Iranian Medicine, 19(9), 618-624.

Głogowski, A., Bryś, K., Perona, P. (2020). Bioclimatic conditions of the Lower Silesia region (South-West Poland) from 1966 to 2017. International Journal of Biometeorology. https://doi.org/10.1007/s00484-020-01970-5

Krüger, E. (2017). Impact of site-specific morphology on outdoor thermal perception: A case-study in a subtropical location. Urban Climate, 21, 123-135. https://doi.org/10.1016/j.uclim.2017.06.001

Kuchcik, M. (2017). Zmiany warunków termicznych w Polsce na przełomie XX i XXI wieku i ich wpływ na umieralność. Prace Geograficzne, 263. Warsaw: IGiPZ PAN

Kuchcik, M. (2020). Mortality and thermal environment (UTCI) in Poland-long-term, multi-city study. International Journal of Biometeorology. https://doi.org/10.1007/s00484-020-01995-w

Kuchcik, M., Błażejczyk, K., Halaś, A. (2021). Long-term changes in hazardous heat and cold stress in humans: multi-city study in Poland. International Journal of Biometeorology. https://doi.org/10.1007/s00484-020-02069-7

Kuchcik, M., Błażejczyk, K., Szmyd, J., Milewski, P., Błażejczyk, A., Baranowski, J. (2013). Potencjał leczniczy klimatu Polski. Warsaw: Wydawnictwo Akademickie SEDNO

Kuchcik, M., Dudek, W., Błażejczyk, K., Milewski, P., Błażejczyk, A. (2016). Two faces to the greenery on housing estates - mitigating climate but aggravating allergy. A Warsaw case study. Urban Forestry \& Urban Greening, 16, 170-181. https://doi.org/10.1016/j.ufug.2016.02.012

Kunert, A. (2010). Modeling of UTCl index in various types of landscape. In: A., Matzarakis, H., Mayer, F.-M., Chmielewski (Eds.), Proceedings of the 7th Conference on Biometeorology, 12-14. April 2010, Albert- Ludwigs-Universität Freiburg, Germany. Berichte des Meteorologischen Institutes der AlbertLudwigs-Universität Freiburg 20, 302-307.

Lindberg, F., Holmer, B., Thorsson, S. (2008). SOLWEIG 1.0 - modelling spatial variations of 3D radiant fluxes and mean radiant temperature in complex urban settings. International Journal of Biometeorology, 52(7), 697-713. https://doi.org/10.1007/s00484-008-0162-7

Lindner-Cendrowska, K., Błażejczyk, K. (2018). Impact of selected personal factors on seasonal variability of recreationist weather perceptions and preferences in Warsaw (Poland). International Journal of Biometeorology, 62(1), 113-125. https://doi.org/10.1007/s00484-016-1220-1

Lindner-Cendrowska, K., Bröde, P. (2021). Impact of biometeorological conditions and air pollution on influenza-like illnesses incidence in Warsaw, International Journal of Biometeorology. https://doi.org/10.1007/s00484-021-02076-2

Liopo, T.N., Cycenko, G.V. (1971). Klimatičeskije uslovija i teplovoje sostojanije čeloveka. Leningrad: Gidrometeoizdat.

Lukić, M., Milovanović, J. (2020). UTCl based assessment of urban outdoor thermal comfort in Belgrade, Serbia. Paper presented at Sinteza 2020 - International Scientific Conference on Information Technology and Data Related Research. https://doi.org/10.15308/Sinteza-2020-70-77

Maronga, B., Banzhaf, S., Burmeister, C., Esch, T., Forkel, R., Fröhlich, D., Fuka, V., Gehrke, K.F., Geletič, J., Giersch, S., Gronemeier, T., Groß, G., Heldens, W., Hellsten, A., Hoffmann, F., Inagaki, A., Kadasch, E., 
Kanani-Sühring, F., Ketelsen, K., Raasch, S. (2020). Overview of the PALM model system 6.0. Geoscientific Model Development, 13, 1335-1372. https://doi.org/10.5194/gmd-13-1335-2020

Matzarakis, A., Rutz, F., Mayer, H. (2010). Modelling radiation fluxes in simple and complex environments: Basics of the RayMan model. International Journal of Biometeorology, 54(2), 131-139. https://doi.org/10.1007/s00484-009-0261-0

Mąkosza, A., Nidzgórska-Lencewicz, J. (2011). Stimuli character thermal conditions in the agglomeration of Szczecin. Prace i Studia Geograficzne, 47, 301-310.

Milewski, P. (2013). Application of the UTCI to the local bioclimate of Poland's Ziemia Kłodzka region. Geographia Polonica, 86(1), 47-54. https://doi.org/10.7163/GPol.2013.6

Nowosad, M., Rodzik, B., Wereski, S., Dobek, M. (2013). The UTCI Index in Lesko and Lublin and its circulation determinants. Geographia Polonica, 86(1), 29-36. https://doi.org/10.7163/GPol.2013.4

Okoniewska, M. (2020). Daily and seasonal variabilities of thermal stress (based on the UTCI) in air masses typical for Central Europe: an example from Warsaw. International Journal of Biometeorology, https://doi.org/10.1007/s00484-020-01997-8

Park, S., Tuller, S.E., Jo, M. (2014). Application of Universal Thermal Climate Index (UTCI) for microclimatic analysis in urban thermal environments. Landscape and Urban Planning, 125, 146-155. https://doi.org/10.1016/j.landurbplan.2014.02.014

Pecelj, M., Błażejczyk, A., Vagić, N. (2021). Extreme biothermal conditions in Vranje health resort region (Serbia) based on UTCl index. Geographia Polonica, 94(2), 201-222. https://doi.org/10.7163/GPol.0201

Petralli, M., Massetti, L., Pearlmutter, D., Brandani, G., Meseri, A., Orlandini, S. (2020). UTCI field measurements in an urban park in Florence (Italy). Miscellanea Geographica, 24(3), 111-117. https://doi.org/10.2478/mgrsd-2020-0017

Santurtún, A., Almendra, R., Fdez-Arroyabe, P., Sanchez-Lorenzo, A., Royé, D., Zarrabeitia, M.T., Santana, P. (2020). Predictive value of three thermal comfort indices in low temperatures on cardiovascular morbidity in the Iberian Peninsula. Science of The Total Environment, 729, 138969. https://doi.org/10.1016/j.scitotenv.2020.138969

Schlünzen, K.H., Hinneburg, D., Knoth, O., Lambrecht, M., Leitl, B., López, S., Lüpkes, C., Panskus, H., Renner, E., Schatzmann, M., Schoenemeyer, T., Trepte, S., Wolke, R. (2003). Flow and transport in the obstacle layer: First results of the micro-scale model MITRAS. Journal of Atmospheric Chemistry, 44(2), 113-130. https://doi.org/10013/epic.14212

Shartova, N.V., Shaposhnikov, D.A., Konstantinov, P.I., Revich, B.A. (2019). Universal Thermal Climate Index (UTCI) applied to determine thresholds for temperature-related mortality. Health Risk Analysis, 3, 83-93. https://doi.org/10.21668/health.risk/2019.3.10.eng

Sievers, U., Früh, B. (2012). A practical approach to compute short-wave irradiance interacting with subgrid-scale buildings. Meteorologische Zeitschrift, 21(4), 349-364. https://doi.org/10.1127/0941-2948/2012/0331

Sievers, U., Kossmann, M. (2016). The cold air drainage model KLAM_21 - Model formulation and comparison with observations. Weather and Climate, 36, 2-24. https://doi.org/10.2307/26779385

Trimmel, H., Weihs, P., Faroux, S., Formayer, H., Hamer, P., Hasel, K., Laimighofer, J., Leidinger, D., Masson, V., Nadeem, I., Oswald, S.M., Revesz, M., Schoetter, R. (2021). Thermal conditions during heat waves of a mid-European metropolis under consideration of climate change, urban development scenarios and resilience measures for the mid-21st century. Meteorologische Zeitschrift, 30(1), 9-32. https://doi.org/10.1127/metz/2019/0966

Urban, A., Kyselý, J. (2014). Comparison of UTCI with other thermal indices in the assessment of heat and cold effects on cardiovascular mortality in the Czech Republic. International Journal of Environmental Research and Public Health, 11(1), 952-967. https://doi.org/10.3390/ijerph110100952

VDI. (2008). VDI 3787-2, Environmental meteorology. Methods for the human biometeorological evaluation of climate and air quality for the urban and regional planning at regional level. Part I: Climate. Düsseldorf: Verlag des Vereins Deutscher Ingenieure. 
Vinogradova, V. (2020). Using the Universal Thermal Climate Index (UTCI) for the assessment of bioclimatic conditions in Russia. International Journal of Biometeorology. https://doi.org/10.1007/s00484-020-01901-4

Wang, Ch., Zhan, W., Liu, Z., Li, J., Li, L., Fu, P., Huang, F., Lai, J., Chen, J., Hong, F., Jiang, S. (2020). Satellite-based mapping of the Universal Thermal Climate Index over the Yangtze River Delta urban agglomeration. Journal of Cleaner Production, 277, 123830.

https://doi.org/10.1016/j.jclepro.2020.123830

Weihs, P., Wagner, J.E., Schreier, S.F., Rieder, H.E., Angelini, F., Blumthaler, M., Fitzka, M., Gobbi, G.P., Kift, R., Kreuter, A., Simic, S., Webb, A. (2012). The influence of the spatial resolution of topographic input data on the accuracy of 3-D UV actinic flux and irradiance calculations. Atmospheric Chemistry and Physics, 12, 2297-2312. https://doi.org/10.5194/acp-12-2297-2012 